\title{
An estimated 400-800 million tons of prey are annually killed by the global spider community
}

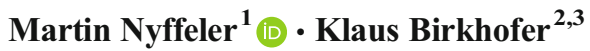

Received: 18 November 2016 /Revised: 31 January 2017 / Accepted: 2 February 2017 /Published online: 14 March 2017

(C) The Author(s) 2017. This article is published with open access at Springerlink.com

\begin{abstract}
Spiders have been suspected to be one of the most important groups of natural enemies of insects worldwide. To document the impact of the global spider community as insect predators, we present estimates of the biomass of annually killed insect prey. Our estimates assessed with two different methods suggest that the annual prey kill of the global spider community is in the range of 400-800 million metric tons (fresh weight), with insects and collembolans composing $>90 \%$ of the captured prey. This equals approximately $1 \%$ of the global terrestrial net primary production. Spiders associated with forests and grasslands account for $>95 \%$ of the annual prey kill of the global spider community, whereas spiders in other habitats are rather insignificant contributors over a full year. The spider communities associated with annual crops contribute less than $2 \%$ to the global annual prey kill. This, however, can be partly explained by the fact that annual crop fields are "disturbed habitats" with a low buildup of spider biomass and that agrobiont spiders often only kill prey over short time periods in a year. Our estimates are supported by the published results of exclusion experiments, showing that the number of herbivorous/detritivorous insects and collembolans increased significantly after spider removal from experimental plots. The presented estimates of the global
\end{abstract}

Communicated by: Sven Thatje

Martin Nyffeler

martin.nyffeler@unibas.ch

1 Section of Conservation Biology, Department of Environmental Sciences, University of Basel, CH-4056 Basel, Switzerland

2 Department of Biology, Lund University, SE-223 62 Lund, Sweden

3 Chair of Ecology, Brandenburg University of Technology Cottbus-Senftenberg, 03046 Cottbus, Germany annual prey kill and the relative contribution of spider predation in different biomes improve the general understanding of spider ecology and provide a first assessment of the global impact of this very important predator group.

Keywords Araneae $\cdot$ Collembola $\cdot$ Insects . Global impact · Predation

\section{Introduction}

Spiders, which evolved from an arachnid ancestor during the Devonian period around 400 million years ago, are among the most common and abundant predators in terrestrial ecosystems (Turnbull 1973; Coddington and Levi 1991; Selden et al. 1991). For instance, Turnbull (1973) calculated an overall mean density of 131 spiders $\mathrm{m}^{-2}$ based on assessments from many different areas of the globe, and Nyffeler (2000) found an overall mean density of 152 spiders $\mathrm{m}^{-2}$ for a large variety of grassland habitats. Under favorable conditions, spiders can reach peak densities of up to 1000 individuals $\mathrm{m}^{-2}$ (Ellenberg et al. 1986). At the present time, $>45,000$ species of spiders are described and those exhibit a very diverse range of lifestyles and foraging behaviors (Wise 1993; Platnick 2014). Barth (1997) partially attributes the evolutionary success of spiders to the fact that they are equipped with highly developed sensory systems providing individuals with detailed information about potential predators and prey in their surroundings. All spiders are carnivores, feeding predominantly on insects/collembolans and to a lesser extent on other spiders (Nyffeler 1999; Birkhofer and Wolters 2012; Pekár and Toft 2015). Very rarely nonarthropod prey and sometimes even plant materials are consumed as a supplement to the arthropod diet (Symondson et al. 2002; Foelix 2011; Nyffeler et al. 2016). Spiders have efficient survival mechanisms given that 
they are so numerous and widespread. Their capability to survive under extreme conditions and to disperse by ballooning through the atmosphere from place to place on silken threads allowed spiders to colonize a wide variety of different terrestrial habitats. Some spiders can travel distances of up to $30 \mathrm{~km}$ in a single day (Thomas et al. 2003). There is hardly any terrestrial area on this globe where spiders would be missing. "....Spiders exist in the most northern islands of the Arctic, the hottest and most arid of deserts, at the highest altitudes of any living organisms, in the depths of caves, in the intertidal zone of ocean shores, in bogs and ponds, on high, arid moorlands, sand dunes, and flood plains" (Turnbull 1973). Because of their high abundance and predominantly insectivorous feeding habits, spiders are suspected to be the main predators of insects (Selden 2016).

Due to their secretive lifestyle - some species are for example nocturnal or hunt in litter and soil habitats - the predatory activities of the spiders remain largely unnoticed and it is therefore difficult to estimate their impact on prey. To illustrate the impact of spiders as insect predators, two arachnologists - W. S. Bristowe from England and A. L. Turnbull from Canadapreviously tried to quantify the food consumption of spiders by means of extrapolations. In his work "A Book of Spiders," Bristowe (1947) estimated that England and Wales are populated by roughly $2.2 \times 10^{12}$ spiders and that these spiders may kill $\approx 2.2 \times 10^{14}$ insects annually. Bristowe (1958) went one step further claiming that the weight of insects consumed by the entire British spider fauna would exceed the combined weight of all the humans in Great Britain. Nyffeler (2000) conducted a recalculation of Bristowe's estimate and came to the conclusion that Bristowe probably overestimated the overall prey kill of the spiders since Great Britain consists predominantly of agricultural land characterized by reduced annual prey consumption. Turnbull (1973), on the other hand, estimated that the average total weight of food annually consumed by spiders would amount to $4.25 \times 10^{3}$ metric tons $\mathrm{km}^{-2}$ land area. This latter value is of the same magnitude as the net primary production in terrestrial ecosystems, which is irreconcilable with ecological theory (Nyffeler 2000).

Here, we provide estimates for the standing biomass of the global spider community and the annual biomass of prey that is killed by the global spider community in individual biome types and worldwide based on literature data.

\section{Methods}

\section{Estimate of the standing biomass of the global spider community}

A total of 65 values of spider biomass $\mathrm{m}^{-2}$ were gathered from the literature. The data were assigned to the following seven groups of terrestrial biomes: (1) tropical forests, (2) temperate and boreal forests, (3) tropical grasslands and savannas, (4) temperate grasslands (incl. old fields, permanent pastures, mown meadows) and Mediterranean shrublands, (5) annual cropland, (6) deserts, and (7) Arctic tundra. To retrieve comparable data, all values were converted to fresh weight $\mathrm{m}^{-2}$ taking into account an average water content of the spider body of $\approx 75 \%$ (Pulz 1987). The data were pooled by computing an average biomass value $\left(\mathrm{g} \mathrm{m}^{-2}\right)$ for each biome type. By extrapolation - using the global land cover data from Saugier et al. (2001) - the standing biomass of the global spider community was then computed (Table 1).

\section{Estimate of the annual prey kill by the global spider community}

We used simple models involving few assumptions as is advised in cases where a field of study is still largely undeveloped (Weathers and Weathers 1983). Two different approaches were taken to estimate the annual prey kill of the global spider community. In the case of method I, the estimate is based on the spiders' food requirements per unit body weight known from the literature in combination with spider biomass $\mathrm{m}^{-2}$ values (data for various biome types being taken from the literature), whereas method II is based on complete assessments of the spiders' annual prey kill (e.g., prey censuses in the field combined with web density estimates) in selected biome types published in the literature. The two estimation methods are based on different sets of studies (with zero overlap of data between the two methods).

Prey items that are killed in webs but remain uneaten are considered prey as well (Nentwig 1987). This issue is playing a role when dealing with spider communities dominated by large-sized orb-weaving spiders known to often kill prey in excess ("wasteful killing"). Accordingly, authors who conducted prey censuses of large-sized orb weavers usually have taken into account the "prey killed in webs but uneaten" in their assessments (see Robinson and Robinson 1974; Kajak et al. 1971; Nyffeler 1976, 1982; Nyffeler and Benz 1978, 1979, 1989; Malt 1996). In other studies dealing predominantly with cursorial hunters and/or small-sized web-building spiders which rarely catch prey in excess under natural conditions (Nyffeler, pers. obs.), this issue was disregarded.

Method I: Based on the spider biomass $\mathrm{m}^{-2}$ values from Table 1 and an assumptive food intake rate (mg prey per $\mathrm{mg}$ spider body mass day ${ }^{-1}$ ), the prey kill $\mathrm{m}^{-2}$ day $^{-1}$ of spider communities for each of the seven biome types was computed. These values were extrapolated to prey kill $\mathrm{m}^{-2}$ year $^{-1}$ for each biome type, considering the length of the spiders' feeding season (in days, see assumptions below). By multiplying the prey kill $\mathrm{m}^{-2}$ year $^{-1}$ with the corresponding area size of a particular biome type (based on Saugier et al. 2001), a prey kill subtotal was derived for each biome type. Summing up the seven subtotals produced an estimate of the annual prey kill of 
the global spider community (Table 2). The estimate derived by method I was based on the following assumptions:

- Assumption 1: Spiders have pulsed feeding patterns, with periods of excessive feeding (when food is very abundant) alternating with episodes of starvation (when prey gets scarce or spiders are inactive) (Turnbull 1973; Anderson 1974). During periods of high feeding activity, the spiders store surplus energy in their body's interstitial tissue as lipid or glycogen (Foelix 2011). The spiders depend on these stored energy reserves during periods of starvation (e.g., on rainy days). To estimate the annual prey kill of the global spider community, we proceed from an overall mean food intake which is intermediate between pronounced high or low daily food consumption. After an extensive literature survey on spider feeding, we propose an average daily food ingestion rate of $\approx 0.1 \mathrm{mg}$ per milligram spider body mass which is the equivalent to $\approx 10 \%$ of a spider's body weight (all values expressed as fresh weight). A daily food intake in this order of magnitude appears to be typical of most species of free-living araneomorph spiders in forests, grasslands, and agroecosystems (see Edgar 1970; Robinson and Robinson 1970; Van Hook 1971; Foelix 2011; Nyffeler, pers. obs.) except a few rare cases of extraordinarily low food intake (e.g., Santana et al. 1990; Henschel 1997). In the case of desert spiders, a daily food ingestion rate of 0.01-0.04 mg per milligram spider body mass was used (see Lubin and Henschel 1996; Henschel 1997). Incidents of wasteful killing (and coupled with it "partial consumption") in cursorial spiders apparently occur very rarely under natural conditions (Nyffeler, pers. obs.), and this issue has therefore not been taken into account in this study.

- Assumption 2: Spiders ingest, on average, $\approx 80 \%$ of the biomass of a killed prey (Edgar 1971; Moulder and Reichle 1972). Hence, we proceed with the assumption that the daily prey kill equals the daily amount of food ingested multiplied by the factor 1.25 .

- Assumption 3: We assume that spiders forage on 365 days year ${ }^{-1}$ in tropical forests, on 240 days year $^{-1}$ in deserts, on 180 days year ${ }^{-1}$ in temperate forests as well as tropical and temperate grasslands, on 120 days year ${ }^{-1}$ in the arctic tundra, and on 60-130 days year ${ }^{-1}$ in annual cropland (Kajak et al. 1971; Robinson and Robinson 1970, 1973, 1974; Breymeyer 1978; Shook 1978; Nyffeler 1982; Byzova et al. 1995). The contribution of winter-active spiders in terms of prey kill in temperate and cold climates (see Aitchison 1984) is considered to be very low and has therefore been neglected.

- Assumption 4: Spider biomass in forests has in most cases been assessed with the Berlese-Tullgren funnel method. This technique is limited to the investigation of spiders on the forest floor, and the calculated biomass values underestimate true biomasses. In temperate forests, at least $20 \%$ of the spider biomass are found in the canopy and understory (see Turnbull 1960; Reichle and Crossley 1967; Moulder and Reichle 1972; Zitnanska 1981). This pattern seems to hold for tropical forests (see Basset et al. 1992; Silva 1996; Yanoviak et al.
2003; Ellwood and Foster 2004; Dial et al. 2006). By multiplying the litter spider biomass values with a correction factor of 1.25 , estimates for the total spider biomass in temperate, boreal, and tropical forests were obtained (Table 1).

- Assumption 5: For biomass $\mathrm{m}^{-2}$ of spiders associated with Mediterranean shrublands, no data are available. We arbitrarily placed this biome type in the category "Temperate grasslands (old fields, permanent pastures, mown meadows)". The area size of Mediterranean shrublands is small $\left(2.8 \times 10^{12} \mathrm{~m}^{2}\right)$ relative to the global terrestrial area, and a possible error resulting from insufficient data can be considered to be negligible.

Method II: The second approach is based on published studies of the annual prey kill of spider communities in various biome types (see Kirchner 1964; Reichle and Crossley 1967; Kajak et al. 1971; Van Hook 1971; Moulder and Reichle 1972; Robinson and Robinson 1974; Luczak 1975; Nyffeler 1976, 1982; Nyffeler and Benz 1978, 1979, 1988a,b, 1989; Schaefer 1990; Ysnel 1993; Jmhasly and Nentwig 1995; Malt 1996). For purposes of comparison, all prey kill values (including those expressed in terms of energy flow) were converted to grams of fresh weight $\mathrm{m}^{-2}$ year $^{-1}$. Values were converted taking into account a prey water content of $\approx 75 \%$ (see Hagstrum 1970; Edgar 1971) and a caloric equivalent of prey of $\approx 23.5 \mathrm{~kJ} \mathrm{~g}^{-1}$ dry weight (mean value from literature data, see Hagstrum 1970; Moulder and Reichle 1972). Thus, $1 \mathrm{~g}$ fresh weight prey biomass equals $\approx 5.875 \mathrm{~kJ}$. By means of extrapolation, the annual prey kill of the global spider community was computed, taking into account the global coverage of the different biome types. The global annual prey kill assessment with method II was based on the following assumptions:

- Assumption 1: Assessments of the annual prey kill of spider communities in tropical forests are currently unavailable. In lieu thereof, a study by Robinson and Robinson (1974) on the prey kill by the web-building spider community of an insecticide-free coffee plantation in New Guinea was used as a surrogate. We were operating on the assumption that the spider communities of tropical insecticide-free coffee plantations are to some degree comparable to those of tropical forests, given that coffee plantations are inhabited to a large extent by tropical woodland spiders (e.g., Nephila maculata) (Robinson and Robinson 1973, 1974; Robinson et al. 1974; Lubin 1978). Robinson and Robinson (1974) came to the conclusion that the web-building spider community in their study killed $16 \mathrm{~g}$ insect prey $\mathrm{m}^{-2}$ year ${ }^{-1}$. These authors suggested that the annual prey kill may even have been twice as high $(\approx 32 \mathrm{~g}$ insect prey $\mathrm{m}^{-2}$ year $^{-1}$ ) if hunting spiders would have been considered. The spider density in this coffee plantation (5.8 individuals $\mathrm{m}^{-2}$ ) was higher than the reported densities in the understory of tropical rain forests (3.3-3.6 individuals $\mathrm{m}^{-2}$; Rypstra 1986; Reagan and Waide 1996). However, we have to take into account that coffee plants reach a height of only 3-3.5 m, whereas tropical forest trees grow to a height of up to $55 \mathrm{~m}$ (Silva 1996). The canopy of tropical forests is inhabited 
by an abundant spider fauna (Basset et al. 1992; Russell-Smith and Stork 1994; Silva 1996; Ellwood and Foster 2004), and it is to be expected that those spiders kill considerable numbers of insects in addition to the insects killed by the spiders of the understory. Thus, it is well possible that the annual prey kill by spiders in tropical forests does exceed the conservative estimate of $16 \mathrm{~g}$ insect prey $\mathrm{m}^{-2}$ year $^{-1}$.

- Assumption 2: Annual prey kill values for temperate forests appear to vary widely. Kirchner (1964) estimated an annual prey kill of $\approx 10 \mathrm{~g} \mathrm{~m}^{-2}$ year $^{-1}$ for a semi-natural temperate forest in Central Europe, whereas lower values were reported for managed temperate forests. The annual prey kill in managed temperate deciduous forests in North America and Central Europe was estimated at $\approx 2 \mathrm{~g} \mathrm{~m}^{-2}$ year $^{-1}$ (calculated by combining data for the spiders of the forest floor, understory, and canopy [Reichle and Crossley 1967; Moulder and Reichle 1972; Schaefer 1990]).

- Assumption 3: Annual prey kill values for unmanaged grasslands vary widely from $\approx 2 \mathrm{~g} \mathrm{~m}^{-2}$ year ${ }^{-1}$ (Ysnel 1993) up to $>10 \mathrm{~g} \mathrm{~m}^{-2}$ year $^{-1}$ (Kajak et al. 1971; Nyffeler and Benz 1989). In order to avoid overestimation, we used a conservative annual prey kill range of 2-10 $\mathrm{g} \mathrm{m}^{-2}$ year $^{-1}$ for grasslands and savannas (Table 3 ). The split in global coverage between unmanaged grassland/savannas $\left(13.7 \times 10^{12} \mathrm{~m}^{2}\right)$ vs. permanent pastures/mown meadows $\left(28.9 \times 10^{12} \mathrm{~m}^{2}\right)$ was based on SAGE/GTAP data http://www.agter.org/images/merlet_c2a cultivablelands_G1.png
- Assumption 4: Published prey kill records for desert spider or arctic tundra communities are not available. Nevertheless, based on published natural history data (Polis 1991; Henschel 1997), we conclude that the annual prey kill in deserts is most likely very low. One might compare deserts to some degree to urban environments where the annual prey kill by spiders is also very low $\left(0.2 \mathrm{~g} \mathrm{~m}^{-2}\right.$ year $^{-1}$; Nyffeler 1976). Supposing that the annual prey kill in deserts might be equally low as in urban areas, we arbitrarily assigned an assumptive value of $\approx 0.2 \mathrm{~g} \mathrm{~m}^{-2}$ year $^{-1}$ to the spider communities in desert areas in order to be able to compute the global annual prey kill with method II. Due to many similarities between tundra and agricultural habitats (regarding population densities, body size composition and faunistic composition), we assume that the annual prey kill in arctic tundra sites might be comparable in magnitude to field crops in Europe $\left(\approx 0.1-1 \mathrm{~g} \mathrm{~m}^{-2}\right.$ year $^{-1}$; Table 3$)$.

Summing up the estimated prey kill subtotals for the seven biome types produced a second estimate of the annual prey kill of the global spider community.

\section{Results}

Based on estimates of the average spider biomass $\mathrm{m}^{-2}$ in various terrestrial biomes, extrapolation suggests that the total standing biomass of the global spider community equals $25.09 \times 10^{12} \mathrm{~g}$ (= 25 million metric tons fresh weight;
Table 1 Estimated standing biomass of the global spider community based on grams per square meter values $(\overline{\mathrm{x}} \pm \mathrm{SE}$, all values expressed as fresh weight)

\begin{tabular}{|c|c|c|c|c|}
\hline Biome type & $\begin{array}{l}\text { Number of } \\
\text { assessments }\end{array}$ & $\begin{array}{l}\overline{\mathrm{x}} \text { Biomass }\left(\mathrm{g} \mathrm{m}^{-2}\right) \\
(B)\end{array}$ & $\begin{array}{l}\text { Area in } \mathrm{m}^{2} \\
(Y)\end{array}$ & $\begin{array}{l}\text { Biomass subtotal }(\mathrm{g}) \\
(B) \times(Y)\end{array}$ \\
\hline Tropical forests ${ }^{\mathrm{a}}$ & 7 & $0.38 \pm 0.147$ & $17.5 \times 10^{12}$ & $6.65 \times 10^{12}$ \\
\hline Temperate and boreal forests ${ }^{\mathrm{b}}$ & 18 & $0.40 \pm 0.054$ & $24.1 \times 10^{12}$ & $9.64 \times 10^{12}$ \\
\hline $\begin{array}{l}\text { Tropical grasslands and } \\
\text { savannas }^{c}\end{array}$ & 11 & $0.18 \pm 0.046$ & $27.6 \times 10^{12}$ & $4.97 \times 10^{12}$ \\
\hline $\begin{array}{l}\text { Temperate grasslands and } \\
\text { Mediterranean shrublands }\end{array}$ & 8 & $0.16 \pm 0.013$ & $17.8 \times 10^{12}$ & $2.85 \times 10^{12}$ \\
\hline Annual cropland ${ }^{\mathrm{e}}$ & 13 & $0.017 \pm 0.004$ & $13.5 \times 10^{12}$ & $0.23 \times 10^{12}$ \\
\hline Deserts $^{\mathrm{f}}$ & 3 & $0.020 \pm 0.006$ & $27.7 \times 10^{12}$ & $0.55 \times 10^{12}$ \\
\hline Arctic tundra ${ }^{\mathrm{g}}$ & 5 & $0.035 \pm 0.009$ & $5.6 \times 10^{12}$ & $0.20 \times 10^{12}$ \\
\hline $\begin{array}{l}\text { Global total (without } \\
\text { ice-covered area) }\end{array}$ & & & $133.8 \times 10^{12}$ & $25.09 \times 10^{12}$ \\
\hline
\end{tabular}

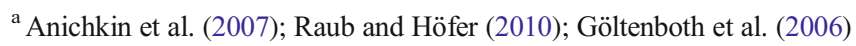

b van der Drift (1951); Kitazawa (1967); Gist and Crossley (1975); Huhta and Koskenniemi (1975); Luczak (1975); Miller and Obrtel (1975); Persson et al. (1980); Axelsson et al. (1984); Meyer et al. (1984); Ellenberg et al. (1986); Niijima (1998); Huhta (2002); Scheu et al. (2003)

${ }^{\mathrm{c}}$ Gillon and Gillon (1967); Malaisse and Benoit (1979); Decaëns et al. (2001)

${ }^{d}$ Stöckli (1950); Cherrett (1964); Delchev and Kajak (1974); Persson and Lohm (1977); Hutchinson and King (1980); Curry (1986)

${ }^{\mathrm{e}}$ Basedow et al. (1991); Basedow (1993); Blumberg et al. (1997); Decaëns et al. (2001); Nyffeler and Sunderland (2003)

${ }^{\mathrm{f}}$ Chew (1961); Mispagel and Sleeper (1983); combined data Polis (1991)/Boulton and Polis (1999)

${ }^{\mathrm{g}}$ Petersen and Luxton (1982); Byzova et al. (1995) 
Table 2 Estimated annual prey kill (fresh weight) of the global spider community assessed with method I

\begin{tabular}{lllll}
\hline Biome type & $\begin{array}{l}\text { Number of } \\
\text { assessments }\end{array}$ & $\begin{array}{l}\text { Prey kill } \\
\left(\mathrm{g} \mathrm{m}^{-2} \text { year }^{-1}\right)\end{array}$ & $\begin{array}{l}\text { Area in m } \\
(X)\end{array}$ & $\begin{array}{l}\text { Prey kill of entire } \\
\left.\text { area }(\mathrm{g} \mathrm{year})^{-1}\right) \\
(X) \times(Y)\end{array}$ \\
\hline Tropical forests & 7 & 17.3 & $17.5 \times 10^{12}$ & $303 \times 10^{12}$ \\
Temperate and boreal forests & 18 & 9.0 & $24.1 \times 10^{12}$ & $217 \times 10^{12}$ \\
Tropical grasslands and savannas & 11 & 4.1 & $27.6 \times 10^{12}$ & $113 \times 10^{12}$ \\
$\begin{array}{l}\text { Temperate grasslands and } \\
\quad \text { Mediterranean shrublands }\end{array}$ & 8 & 3.6 & $17.8 \times 10^{12}$ & $64 \times 10^{12}$ \\
$\begin{array}{l}\text { Annual cropland } \\
\text { Deserts }\end{array}$ & 13 & 0.25 & $13.5 \times 10^{12}$ & $3.4 \times 10^{12}$ \\
Arctic tundra & 3 & 0.6 & $27.7 \times 10^{12}$ & $16.6 \times 10^{12}$ \\
Global total & 5 & 0.7 & $5.6 \times 10^{12}$ & $3.9 \times 10^{12}$ \\
$\quad$ without ice-covered area) & & & $133.8 \times 10^{12}$ & $721 \times 10^{12}$ \\
\hline
\end{tabular}

Computation of the prey kill values for each type of biome based on data (spider biomass $\mathrm{m}^{-2}$ ) from Table 1
Table 1). Biomass estimates $\mathrm{m}^{-2}$ follow the order forests $>$ grasslands/shrublands $>$ croplands, deserts, and tundra, which also reflects the order of total spider biomass per biome type worldwide.

The calculation of the annual prey kill by the global spider community with method I resulted in an estimate of $721 \times 10^{12}$ g year $^{-1}$ (= roughly 700 million tons year ${ }^{-1}$; Table 2). To derive an estimate to which degree reduced feeding activity during rainy days would affect the global annual prey kill, we recalculated this estimate assuming that it rained during one third of the feeding season with no prey being captured on rainy days. This simple scenario still leads to a global annual prey kill of 460 million tons year ${ }^{-1}$. Estimates derived from method I therefore suggest that the annual prey kill of the global spider community may be in the range of 460 700 million tons year ${ }^{-1}$. Our assessment with method II produced an estimate of the global annual prey kill of 395$805 \times 10^{12}$ g year $^{-1}$ (= roughly 400-800 million tons year ${ }^{-1}$; Table 3). The estimates computed with the two methods are highly comparable in magnitude (Tables 2 and 3 ). Together, the two different methods suggest that the global annual prey kill is presumably in the range of 400-800 million tons year ${ }^{-1}$.

\section{Discussion}

Our extrapolations resulted in an estimated annual prey kill by the global spider community in the range of 400-800 million
Table 3 Estimated annual prey kill by the global spider community (expressed as fresh weight $g$ year $\left.{ }^{-1}\right)$ assessed with method II

\begin{tabular}{|c|c|c|c|c|}
\hline Biome type & $\begin{array}{l}\text { Number of } \\
\text { assessments }\end{array}$ & $\begin{array}{l}\text { Prey kill } \\
\left(\mathrm{g} \mathrm{m}^{-2} \text { year }^{-1}\right) \\
(X)\end{array}$ & $\begin{array}{l}\text { Area in } \mathrm{m}^{2} \\
(Y)\end{array}$ & $\begin{array}{l}\text { Prey kill of entire } \\
\text { area }\left(g_{\text {year }}^{-1}\right) \\
(X) \times(Y)\end{array}$ \\
\hline Tropical forests ${ }^{\mathrm{a}}$ & 1 & 16 & $17.5 \times 10^{12}$ & $280 \times 10^{12}$ \\
\hline Temperate and boreal forests ${ }^{\mathrm{b}}$ & 3 & $2-10$ & $24.1 \times 10^{12}$ & $48-240 \times 10^{12}$ \\
\hline Unmanaged grasslands and savannas ${ }^{\mathrm{c}}$ & 7 & $2-10$ & $13.7 \times 10^{12}$ & $27-137 \times 10^{12}$ \\
\hline $\begin{array}{l}\text { Permanent pastures and mown } \\
\text { meadows/Mediterranean } \\
\text { shrublands }^{\mathrm{d}}\end{array}$ & 2 & $1-4$ & $31.7 \times 10^{12}$ & $32-127 \times 10^{12}$ \\
\hline Annual cropland ${ }^{\mathrm{e}}$ & 4 & $0.1-1$ & $13.5 \times 10^{12}$ & $1-14 \times 10^{12}$ \\
\hline $\begin{array}{l}\text { Others (urban areas, deserts, } \\
\text { arctic tundra, etc. })^{\mathrm{f}}\end{array}$ & 1 & 0.2 & $33.3 \times 10^{12}$ & $7 \times 10^{12}$ \\
\hline $\begin{array}{l}\text { Global total (without } \\
\text { ice-covered area) }\end{array}$ & & & $133.8 \times 10^{12}$ & $395-805 \times 10^{12}$ \\
\hline
\end{tabular}

${ }^{a}$ Robinson and Robinson (1974)

${ }^{\mathrm{b}}$ Kirchner (1964); combined data Reichle and Crossley (1967)/Moulder and Reichle (1972); Schaefer (1990)

${ }^{\mathrm{c}}$ Bristowe (1958); Kajak et al. (1971); Van Hook (1971); Nyffeler and Benz (1978, 1989); Ysnel (1993); Malt (1996)

${ }^{d}$ Kajak et al. (1971); Nyffeler (1982)

${ }^{\mathrm{e}}$ Luczak (1975); Nyffeler and Benz (1979); Nyffeler and Benz (1988a,b); Jmhasly and Nentwig (1995)

${ }^{\mathrm{f}}$ Nyffeler (1976) 
tons year ${ }^{-1}$ (Tables 2 and 3 ), which equals $\approx 1 \%$ of the global terrestrial net primary production (see Vitousek et al. 1986). For comparison, the human world population does consume an estimated 400 million tons of meat and fish annually (Bruinsma 2003; Food and Agriculture Organization of the United Nations 2014). Furthermore, our estimates for spiders appear to be of the same order of magnitude as the prey kill by whales (Cetacea) in the world's oceans which has been estimated to be in the range of 280-500 million tons annually (Yodzis 2001). By contrast, the annual food consumption of all the world's seabirds is estimated at 70 million tons (Brooke 2004).

\section{Which prey groups are killed by the spider global community?}

Overall, fewer than 10 arthropod orders (Diptera, Hemiptera, Hymenoptera, Collembola, Coleoptera, Lepidoptera, Orthoptera, and Araneae) make up the majority of the prey of spiders (e.g., Turnbull 1960; Kajak et al. 1968, 1971; Robinson and Robinson 1970, 1973, 1974; Nyffeler 1982, 1999). Apart from insects and collembolans, spiders are another important component in spider diets ("intraguild predation" sensu Polis et al. 1989). Spider communities in the warmer areas (often dominated by cursorial hunters) have a higher percentage of spiders in their diets than spider communities in the colder climates (see Nyffeler 1999; Nyffeler and Sunderland 2003) and cursorial spiders feed more frequently on other spiders than web-builders (Birkhofer and Wolters 2012). Spiders feed on all stages (eggs, immatures, and adults) of their arthropod prey (Nyffeler et al. 1990). In addition to this, some larger spiders occasionally prey on earthworms, slugs, snails, and small vertebrates (Foelix 2011). Also, spiders have been reported supplementing their animal diet by feeding on plant materials (Nyffeler et al. 2016).

\section{Relative contribution of different biome categories to the global annual prey kill}

Spiders in forests and grasslands accounted for more than 95\% of the annual prey kill of the global spider community (i.e., 697 million tons year ${ }^{-1}$ estimated with method I and 387-784 million tons year ${ }^{-1}$ with method II), whereas spiders in other biomes (i.e., annual crop fields, urban areas, deserts, arctic tundra) were less significant contributors to the global prey kill (24 million tons year ${ }^{-1}$ estimated with method I and 8-21 million tons year ${ }^{-1}$ with method II, Tables 2 and 3). Forests, grasslands, and savannas cover an area of 87 million $\mathrm{km}^{2}$, which is about two thirds of the global terrestrial surface area (Saugier et al. 2001). Forests, grasslands, and savannas are less frequently disturbed than, e.g., agricultural or urban areas and allow spider populations to build up a higher biomass (Table 1). Both these differences explain the high prey kill in these biomes (Tables 2 and 3). These spiders further feed on many forest and grassland pest species underlining the important role of spiders as providers of biological control services (e.g., Juillet 1961; Kirchner 1964, 1967; Pointing 1966; Kajak et al. 1968, 1971; Van Hook 1971; Jennings and Pase 1975; Furuta 1977; Schmitz 1993; Oedekoven and Joern 1998). However, spiders do not only kill pest prey but also consume other beneficial arthropods (including large numbers of honey bees) in forest and grassland habitats (Nyffeler and Benz 1978; Malt 1996).

In relation to pest control, it is noteworthy that the spiders associated with annual crops only contribute less than $2 \%$ to the global annual prey kill. This can be explained by the fact that annual crop fields are "disturbed habitats" characterized by low spider biomass and a relatively short feeding season (Luczak 1979; Nyffeler and Benz 1979; Nyffeler et al. 1994a). Nevertheless, in wheat-, rice-, and cottongrowing areas with no or very low pesticide usage, the presence of spiders (in combination with other predators) may at times have a beneficial effect in slowing down the population growth of hemipteran pests (Kiritani et al. 1972; Sunderland et al. 1986; Nyffeler and Benz 1987, 1988a,b; Nyffeler et al. 1992, 1994a,b; Jmhasly and Nentwig 1995; Birkhofer et al. 2008, 2016).

Desert spiders only account for a small percentage $(\leq 2 \%)$ of the global annual prey kill, but deserts cover a vast area (27.7 million $\mathrm{km}^{2}$ ) of the globe (Saugier et al. 2001). Due to adverse environmental conditions, prey availability in deserts is very low and these biomes are often populated by spiders in very low densities (Shook 1978; Polis 1991; Lubin and Henschel 1996; Henschel 1997). There are exceptions to this trend. Polis and Hurd (1995) described small desert islands in the Gulf of California, Mexico, where spiders occur in extraordinarily high numbers as a consequence of allochthonous energy input from the ocean. But the area of such island deserts is so small compared to the globe's total desert area that its contribution to the global spider prey kill must be considered as negligible. Despite the fact that prey biomass killed $\mathrm{m}^{-2}$ by desert spiders appears to be relatively low compared to spider communities in other biomes, these arachnids are noticeable top predators in desert food webs (Polis and McCormick 1986; Polis 1991; Polis and Yamashita 1991). The relative contribution of spiders of the Arctic tundra to the global annual prey kill is equally low as for desert-living spider communities $(<1 \%)$. The climatic seasonality and short foraging periods in this biome certainly contribute to those low estimates. However, spiders in the Arctic tundra (dominated by individuals from the family Linyphiidae) play an important ecological role by entrapping in their webs nutrients that originated from wind-blown allochthonous inputs (mostly chironomid midges). These nutrients are thereafter retained within the system and contribute to early stages of ecosystem development (Hodkinson et al. 2001). 
Table 4 Estimated global number of species of highly specialized predators, parasitoids, and parasites of spiders/spider eggs

\begin{tabular}{|c|c|c|c|}
\hline Taxon & $\begin{array}{l}\text { Estimated number } \\
\text { of species }\end{array}$ & Hunting strategy & Source \\
\hline \multicolumn{4}{|l|}{ Hymenoptera } \\
\hline Pompilidae & $\begin{array}{l}\approx 5000 \text { described; } \\
\text { possibly } \geq 500 \\
\text { undescribed }\end{array}$ & Predator of spiders & $\begin{array}{l}\text { Pitts et al. 2006; James Pitts, } \\
\text { pers. comm. }\end{array}$ \\
\hline $\begin{array}{l}\text { Crabronidae (Miscophus, } \\
\text { Pison, Pisonopsis, } \\
\text { Trypoxylon) }\end{array}$ & $\approx 1000$ & Predator of spiders & Pulawski 2016 \\
\hline $\begin{array}{l}\text { Sphecidae (Chalybion, } \\
\text { Sceliphron) }\end{array}$ & $\approx 80$ & Predator of spiders & Pulawski 2016 \\
\hline Ichneumonidae (Polysphincta) & $\approx 190$ & Spider ectoparasitoid & Gauld and Dubois 2006 \\
\hline $\begin{array}{l}\text { Ichneumonidae (excluding } \\
\text { Polysphincta) }\end{array}$ & Dozens & Egg sac parasitoid & $\begin{array}{l}\text { Austin 1985; } \\
\quad \text { Fitton et al. } 1987\end{array}$ \\
\hline Scelionidae (Baeines) & $\begin{array}{l}\approx 440 \text { described; } \\
\text { possibly } \approx 2500 \\
\text { undescribed }\end{array}$ & Egg parasitoid & $\begin{array}{l}\text { Iqbal and Austin 2000; } \\
\text { Johnson 2016; Lubomir } \\
\text { Masner, pers. comm. }\end{array}$ \\
\hline Encyrtidae (Amira) & Several & Egg parasite & Noyes 1977 \\
\hline $\begin{array}{l}\text { Eulophidae (Aranobroter, } \\
\text { Aprostocetus, Baryscapus, } \\
\text { Pediobius, and others) }\end{array}$ & $\begin{array}{l}\approx 20 \text { described; } \\
\quad \text { possibly } \approx 80 \\
\text { undescribed }\end{array}$ & Egg predator & $\begin{array}{l}\text { LaSalle 1990; John LaSalle, } \\
\text { pers. comm. }\end{array}$ \\
\hline Eupelmidae (Arachnophaga) & Several & Egg predator & Muma and Stone 1971 \\
\hline $\begin{array}{l}\text { Formicidae (Proceratium, } \\
\text { Discothyrea) }\end{array}$ & Several & Egg predator & $\begin{array}{l}\text { Brown 1980; } \\
\quad \text { Dejean et al. } 1999\end{array}$ \\
\hline $\begin{array}{l}\text { Pteromalidae } \\
\text { (Arachnopteromalus) }\end{array}$ & Several & Egg predator & $\begin{array}{l}\text { Peaslee and Peck 1983; } \\
\quad \text { Austin } 1985\end{array}$ \\
\hline \multicolumn{4}{|l|}{ Diptera } \\
\hline $\begin{array}{l}\text { Acroceridae (Acrocera, } \\
\text { Ogcodes, and others) }\end{array}$ & $\approx 500$ & Spider endoparasitoid & Borkent and Schlinger 2008 \\
\hline Tachinidae & 1 & Spider endoparasitoid & Vincent 1985 \\
\hline Therevidae & 1 & External parasite & Ramírez 1995 \\
\hline Chloropidae (Pseudogaurax) & Several & Egg predator & Wheeler 2003 \\
\hline Drosophilidae (Titanochaeta) & 11 & Egg predator & O’Grady et al. 2003 \\
\hline Ephydridae (Trimerina) & 1 & Egg predator & Foote 1984 \\
\hline Phoridae (Megaselia) & Dozens & $\begin{array}{l}\text { Egg predator/spider } \\
\text { endoparasitoid }\end{array}$ & Disney 2008, 2012 \\
\hline $\begin{array}{l}\text { Sarcophagidae (Baranovisca, } \\
\text { Mehria) }\end{array}$ & 22 & Egg predator/parasitoid & $\begin{array}{l}\text { Pape 1996; Thomas Pape, } \\
\text { pers. comm. }\end{array}$ \\
\hline \multicolumn{4}{|l|}{ Lepidoptera } \\
\hline $\begin{array}{r}\text { Cosmopterigidae } \\
\text { (Anatrachyntis) }\end{array}$ & 1 & Egg predator & Austin 1985 \\
\hline $\begin{array}{l}\text { Stathmopodidae } \\
\quad \text { (Stathmopoda) }\end{array}$ & 1 & Egg predator & Austin 1985 \\
\hline \multicolumn{4}{|l|}{ Neuroptera } \\
\hline Mantispidae & 334 & Egg predator & Ohl 2004 \\
\hline \multicolumn{4}{|l|}{ Odonata } \\
\hline Pseudostigmatidae & $\approx 20$ & Predator of spiders & Ingley et al. 2012 \\
\hline \multicolumn{4}{|l|}{ Hemiptera } \\
\hline Reduviidae (Stenolemus) & Several & Predator of spiders & Soley et al. 2011 \\
\hline \multicolumn{4}{|l|}{ Acari } \\
\hline \multicolumn{3}{|l|}{ Scorpiones } & Welbourn and Young 1988 \\
\hline Buthidae (Isometroides) & 1 & Predator of spiders & Main 1956 \\
\hline \multicolumn{4}{|l|}{ Nematodes } \\
\hline Mermitidae & Possibly hundreds & Parasite of spiders & $\begin{array}{l}\text { Poinar 1987; George Poinar, } \\
\text { pers. comm. }\end{array}$ \\
\hline \multicolumn{4}{|l|}{ Fungi-Hypocreales } \\
\hline $\begin{array}{l}\text { Cordycipitaceae } \\
\text { (Akanthomyces, Cordyceps, } \\
\text { Gibellula, Torrubiella) and } \\
\text { others }\end{array}$ & $\approx 50-100$ & Parasite of spiders & $\begin{array}{l}\text { Evans 2013; } \\
\quad \text { Nyffeler et al. } 2016\end{array}$ \\
\hline Total & $\approx 8000-10,000$ & & \\
\hline
\end{tabular}




\section{Experimental evidence supporting our estimates of the global annual prey kill}

Our estimates of the global annual prey kill (Tables 2 and 3) imply that spiders exert considerable predation pressure on insect populations, especially in forests and grasslands. These estimates are supported by exclusion studies in forest and grassland habitats in different parts of the world (Clarke and Grant 1968; Kajak et al. 1968; Schmitz 1993; Oedekoven and Joern 1998; Lawrence and Wise 2000; Tanhuanpää et al. 2001). After spiders had been manually removed from experimental exclosure plots, a significant increase of the number of insects and collembolans was noticed compared to control plots with spiders. Greenstone (1978), however, stated that even though spiders can achieve very high densities and consume large quantities of insect prey, they may not necessarily have a significant role in the regulation of insect populations. Spiders depress herbivorous insect populations by 1-20\% (Juillet 1961; Pointing 1966; Kirchner 1967; Furuta 1977; Nakamura and Nakamura 1977; Oedekoven and Joern 1998; Tanhuanpää et al. 2001). Acting in concert with other natural enemies (ants, ground beetles, predaceous bugs, birds, etc.), spider communities certainly exert significant predation pressure on herbivorous insect populations (e.g., Kajak et al. 1971).

\section{Further evidence in support of our theory of high global prey kill by spiders}

There is also indirect support for the significance of spider predation in terrestrial biomes: a large number of insect species have evolved morphological and/or behavioral adaptations to reduce the risk of predation by spiders (see Eisner et al. 1964; Wise 1993). This concerns in particular the adults of ten thousands of species of moths, butterflies, and skippers (Lepidoptera) which evolved an escape mechanism allowing them to disentangle themselves from the webs of ecribellate spiders (see Eisner et al. 1964). Eisner et al. (1964) stated "....Moths, by virtue of the loose scales that cover their wings and bodies, are admirably adapted to elude capture by orbweaving spiders. Rather than sticking to the web, these may simply lose some of their scales to the viscid threads, and then fly on."

Further indirect evidence for the enormous ecological significance of spiders is that they serve as a food source for an incredibly diverse complex of arthropod-eating carnivores and, given our estimated global spider biomass (25 million metric tons fresh weight), spiders certainly are a crucial source of nutrition for many predator species. An estimated 8000 10,000 species of highly specialized predators/parasitoids/parasites feed exclusively on spiders, all of them being evolutionarily adapted to this special lifestyle (Table 4). In addition to this, an estimated 3000-5000 polyphagous bird species include spiders in their diets. Many of these bird species feed heavily on spiders in certain periods (i.e., spiders constituting 20-95\% of the birds' prey biomass [Kuitunen and Törmälä 1983; Poulin and Lefebvre 1996; Naef-Daenzer et al. 2000]). Likewise, many species of frogs, toads, salamanders, newts, lizards, snakes, shrews, mice, rats, and bats include spiders in their diets (Shine 1986; Schulz and Wainer 1997; Van Sluys and Rocha 1998; Marques et al. 2006). Even fish from more than 20 families have been reported consuming spiders that mistakenly landed on the water surface after ballooning across lakes or that fell into water from overhanging trees (e.g., Bristowe 1941; David and Closs 2003).

\section{Nonlethal effects of spiders on prey additionally increase their global impact}

In recent years, researchers have shown experimentally that spiders not only affect insects by inflicting mortality on them, they additionally have indirect (nonlethal) effects by intimidating them to the point where insects reduce their feeding activity in the presence of spiders in order to decrease predation risk (Schmitz et al. 1997; Schmitz 1998; Snyder and Wise 2000; Hlivko and Rypstra 2003). Such nonlethal effects of spiders can result in reduced herbivore damage. Hlivko and Rypstra (2003) noted “....the potential impact of spiders may be underestimated in food web studies that only consider predation rates...." Thus, the spiders' huge predation impact documented in our study (Tables 2 and 3) is even further enhanced due to additional nonlethal effects.

\section{Concluding remarks}

The estimated standing biomass of the global spider community is impressive ( $\approx 25$ million tons, Table 1$)$. There are few groups of terrestrial predaceous arthropods that can compare with spiders in terms of abundance and biomass. An exception are ants (Formicidae estimated at approx. 280 million tons, Hölldobler and Wilson 1994), but most species of ants are omnivorous and utilize a much broader range of food resources including considerable amounts of plant materials (Hölldobler and Wilson 1990). Here, we suggest that the predation impact of spider communities is particularly high in forest and grassland biomes, with considerably lower impact in desert, urban, and tundra biomes. These estimates emphasize the important role that spider predation plays in semi-natural and natural habitats, as many economically important pests and disease vectors breed in those forest and grassland biomes. We hope that these estimates and their significant magnitude raise public awareness and increase the level of appreciation for the important global role of spiders in terrestrial food webs. 
Acknowledgements The following scientists provided us with information on current total numbers of species of particular taxonomic groups of predators, parasitoids, and parasites of spiders/spider eggs: Andrew Austin (University of Adelaide), Henry Disney (Museum of Zoology, Cambridge University), Ian David Gauld (formerly Natural History Museum London), Norman Johnson (Ohio State University), John LaSalle (Australian National Insect Collection, CSIRO, Canberra), Lubomir Masner (Canadian National Collection of Insects, Arachnids and Nematodes, Ottawa), Michael Ohl (Natural History Museum, Humboldt University of Berlin), Thomas Pape (Natural History Museum of Denmark, Copenhagen), James Pitts (Utah State University), George Poinar (Oregon State University), and Wojciech Pulawski (California Academy of Sciences). All these people are greatly acknowledged. Furthermore, we wish to thank Bill Symondson (Cardiff University) and two anonymous reviewers for their valuable comments on an earlier draft.

Open Access This article is distributed under the terms of the Creative Commons Attribution 4.0 International License (http:// creativecommons.org/licenses/by/4.0/), which permits unrestricted use, distribution, and reproduction in any medium, provided you give appropriate credit to the original author(s) and the source, provide a link to the Creative Commons license, and indicate if changes were made.

\section{References}

Aitchison CW (1984) Low temperature feeding by winter-active spiders. J Arachnol 12:297-305

Anderson JF (1974) Responses to starvation in the spiders Lycosa lenta Hentz and Filistata hibernalis (Hentz). Ecology 55:576-585

Anichkin AE, Belyaeva NV, Dovgobrod IG, Shveenkova YB, Tiunov AV (2007) Soil microarthropods and macrofauna in monsoon tropical forests of Cat Tien and Bi Dup-Nui Ba National Parks, Southern Vietnam. Biol Bull 34:498-506

Austin AD (1985) The function of spider egg sacs in relation to parasitoids and predators, with special reference to the Australian fauna. J Nat Hist 19:359-376

Axelsson B, Lohm U, Persson T (1984) Enchytraeids, lumbricids and soil arthropods in a northern deciduous woodland - a quantitative study. Holarct Ecol 7:91-103

Barth FG (1997) Vibratory communication in spiders: adaptation and compromise at many levels. In: Lehrer M (ed) Orientation and communication in arthropods. Birkhäuser, Basel, pp 247-272

Basedow T (1993) Predatory arthropods in cabbage terraces under different conditions in the Cordillera Region of Luzon, Philippines. B Entomol Res 83:313-319

Basedow T, Braun C, Lühr A, Naumann J, Norgall T, Yanes-Yanes G (1991) Abundanz, Biomasse und Artenzahl epigäischer Raubarthropoden intensiv bewirtschafteter Weizen- und Rübenfelder: Unterschiede und ihre Ursachen. Ergebnisse eines dreistufigen Vergleichs in Hessen, 1985-1988. Zool Jahrb Abt Syst Oekol Geogr Tiere 118:87-116

Basset Y, Aberlenc HP, Delvare G (1992) Abundance and stratification of foliage arthropods in a lowland rain forest of Cameroon. Ecol Entomol 17:310-318

Birkhofer K, Wolters V (2012) The global relationship between climate, net primary production and the diet of spiders. Glob Ecol Biogeogr 21:100-108

Birkhofer K, Gavish-Regev E, Endlweber K, Lubin YD, Von Berg K, Wise DH, Scheu S (2008) Cursorial spiders retard initial aphid population growth at low densities in winter wheat. B Entomol Res 98: 249-255
Birkhofer K, Arvidsson F, Ehlers D, Mader VL, Bengtsson J, Smith HG (2016) Organic farming affects the biological control of hemipteran pests and yields in spring barley independent of landscape complexity. Landscape Ecol 31:567-579

Blumberg AJY, Hendrix PF, Crossley DA (1997) Effects of nitrogen source on arthropod biomass in no-tillage and conventional tillage grain sorghum agroecosystems. Environ Entomol 26:31-37

Borkent CJ, Schlinger EI (2008) Flower-visiting and mating behaviour of Eulonchus sapphirinus (Diptera: Acroceridae). Can Entomol 140: 250-256

Boulton AM, Polis GA (1999) Phenology and life history of the desert spider, Diguetia mojavea (Araneae, Diguetidae). J Arachnol 27: 513-521

Breymeyer A (1978) Analysis of the trophic structure of some grassland ecosystems. Pol Ecol Stud 4:55-128

Bristowe WL (1941) The comity of spiders, vol II. Ray Society, London Bristowe WL (1947) A book of spiders. King Penguin Books, London

Bristowe WL (1958) The world of spiders. Collins, London

Brooke MDL (2004) The food consumption of the world's seabirds. Proc R Soc Lond B (Supp) 271:S246-S248

Brown WL (1980) A remarkable new species of Proceratium, with dietary and other notes on the genus (Hymenoptera: Formicidae). Psyche (Camb) 86:337-346

Bruinsma J (2003) World agriculture: towards 2015/2030. An FAO perspective, Earthscan, London

Byzova JB, Uvarov AV, Petrova AD (1995) Seasonal changes in communities of soil invertebrates in tundra ecosystems of Hornsund, Spitsbergen. Pol Polar Res 16:245-266

Cherrett JH (1964) The distribution of spiders on the Moor House National Nature Reserve, Westmoreland. J Anim Ecol 33:27-48

Chew RM (1961) Ecology of the spiders of a desert community. J New York Entomol S 69:5-41

Clarke RD, Grant PR (1968) An experimental study of the role of spiders as predators in a forest litter community. Part 1. Ecology 49:11521154

Coddington JA, Levi HW (1991) Systematics and evolution of spiders (Araneae). Annu Rev Ecol Syst 22:565-592

Curry JP (1986) Above-ground arthropod fauna of four Swedish cropping systems and its role in carbon and nitrogen cycling. J Appl Ecol 23: 853-870

David BO, Closs GP (2003) Seasonal variation in diel activity and microhabitat use of an endemic New Zealand stream-dwelling galaxiid fish. Freshw Biol 48:1765-1781

Decaëns T, Lavelle P, Jiménez JJ, Escobar G, Rippstein G, Schneidmadl J, Sanz JI, Hoyos P, Thomas RJ (2001) Impact of land management on soil macrofauna in the eastern plains of Colombia. In: Jiménez JJ, Thomas RJ (eds) Nature's plow: soil macroinvertebrate communities in the neotropical savannas of Colombia. Publ. 324, Centro Internacional de Agricultura Tropical, Cali, pp. 19-41

Dejean A, Grimal A, Malherbe MC, Suzzoni JP (1999) From specialization in spider egg predation to an original nesting mode in a "primitive" ant: a new kind of lestobiosis. Naturwissenschaften 86:133-137

Delchev K, Kajak A (1974) Analysis of a sheep pasture ecosystem in the Pieniny mountains (the Carpathians). XVI. Effect of pasture management on the number and biomass of spiders (Araneae) in two climatic regions (the Pieniny and the Sredna Gora mountains). Ekol Pol 22:693-710

Dial RJ, Ellwood MD, Turner EC, Foster WA (2006) Arthropod abundance, canopy structure, and microclimate in a Bornean lowland tropical rain forest. Biotropica 38:643-652

Disney RHL (2008) Natural history of the scuttle fly, Megaselia scalaris. Annu Rev Entomol 53:39-60

Disney RHL (2012) Scuttle flies: the Phoridae. Springer Science \& Business Media, Dordrecht

Edgar WD (1970) Prey and feeding behavior of adult females of the wolf spider Pardosa amentata (Clerck). Neth J Zool 20:487-491 
Edgar WD (1971) Aspects of the ecological energetics of the wolf spider Pardosa (Lycosa) lugubris (Walckenaer). Oecologia 7:136-154

Eisner T, Alsop R, Ettershank G (1964) Adhesiveness of spider silk. Science 146:1058-1061

Ellenberg H, Mayer R, Schauermann J (1986) Oekosystemforschung Ergebnisse des Sollingprojektes 1966-1986. Ulmer, Stuttgart

Ellwood MD, Foster WA (2004) Doubling the estimate of invertebrate biomass in a rainforest canopy. Nature 429:549-551

Evans HC (2013) Fungal pathogens of spiders. In: Nentwig W (ed) Ecophysiology of spiders. Springer, Berlin-Heidelberg, pp 107-121

Fitton MG, Shaw MR, Austin AD (1987) The Hymenoptera associated with spiders in Europe. Zool J Linnean Soc 90:65-93

Foelix RF (2011) Biology of spiders, 3rd edn. Oxford University Press, New York

Food and Agriculture Organization of the United Nations (2014) The state of world fisheries and aquaculture. FAO, Rome

Foote BA (1984) Biology of Trimerina madizans, a predator of spider eggs (Diptera: Ephydridae). P Entomol Soc Wash 86:486-492

Furuta K (1977) Evaluation of spiders, Oxyopes sertatus and O. badius (Oxyopidae) as a mortality factor of gypsy moth, Lymantria dispar (Lepidoptera: Lymantriidae) and pine moth, Dendrolimus spectabilis: Lepidoptera: Lasiocampidae. Appl Entomol Zool 12:313-324

Gauld ID, Dubois J (2006) Phylogeny of the Polysphincta group of genera (Hymenoptera: Ichneumonidae; Pimplinae): a taxonomic revision of spider ectoparasitoids. Syst Entomol 31:529-564

Gillon Y, Gillon D (1967) Recherches écologiques dans la savane de Lamto (Côte-d'Ivoire): cycle annuel des effectifs et des biomasses d'arthropodes de la strate herbacée. Terre Vie 21:262-277

Gist CS, Crossley DA Jr (1975) The litter arthropod community in a southern Appalachian hardwood forest: numbers, biomass and mineral element content. Am Midl Nat 93:107-122

Göltenboth F, Langenberger G, Widman P (2006) Tropical lowland evergreen rainforest. In: Göltenboth F, Timotius KH, Milan PP, Margraf J (eds) Ecology of insular Southeast Asia. The Indonesian Archipelago. Elsevier, Amsterdam, pp 297-383

Greenstone MH (1978) The numerical response to prey availability of Pardosa ramulosa (McCook) (Araneae: Lycosidae) and its relationship to the role of spiders in the balance of nature. Sym Zool S London 42:183-193

Hagstrum DW (1970) Ecological energetics of the spider Tarentula kochi (Araneae: Lycosidae). Ann Entomol Soc Am 63:1297-1304

Henschel JR (1997) Psammophily in Namib Desert spiders. J Arid Environ 37:695-707

Hlivko JT, Rypstra AL (2003) Spiders reduce herbivory: nonlethal effects of spiders on the consumption of soybean leaves by beetle pests. Ann Entomol Soc Am 96:914-919

Hodkinson ID, Coulson SJ, Harrison JA, Webb NR (2001) What a wonderful web they weave: spiders, nutrient capture and early ecosystem development in the high Arctic - some counter intuitive ideas on community assembly. Oikos 95:349-352

Hölldobler B, Wilson EO (1990) The ants. Belknap Press, Cambridge

Hölldobler B, Wilson EO (1994) Journey to the ants: a story of scientific exploration. Harvard University Press, Cambridge

Huhta V (2002) Soil macroarthropod communities in planted birch stands in comparison with natural forests in central Finland. Appl Soil Ecol 20:199-209

Huhta V, Koskenniemi A (1975) Numbers, biomass and community respiration of soil invertebrates in spruce forests at two latitudes in Finland. Ann Zool Fenn 12:164-182

Hutchinson KJ, King KL (1980) The effects of sheep stocking level on invertebrate abundance, biomass and energy utilization in a temperate, sown grassland. J Appl Ecol 17:369-387

Ingley SJ, Bybee SM, Tennessen KJ, Whiting MF, Branham MA (2012) Life on the fly: phylogenetics and evolution of the helicopter damselflies (Odonata, Pseudostigmatidae). Zool Scr 41:637-650
Iqbal M, Austin AD (2000) A preliminary phylogeny for the Baeini (Hymenoptera: Scelionidae): endoparasitoids of spider eggs. In: Austin A, Dowton M (eds) Hymenoptera: evolution, biodiversity and biological control. CSIRO Publishing, Collingwood, pp 178-191

Jennings DT, Pase HA (1975) Spiders preying on Ips bark beetles. Southwest Nat 20:225-229

Jmhasly P, Nentwig W (1995) Habitat management in winter wheat and evaluafion of subsequent spider predation on insect pests. Acta Oecol 16:389-403

Johnson NF (2016) Hymenoptera Online (HOL). Ohio State University. http://hol.osu.edu/ Accessed 7 September 2016

Juillet JA (1961) Observations on arthropod predators of the European pine shoot moth, Rhyacionia buoliana (Schiff.) (Lepidoptera: Olethreutidae), in Ontario. Can Entomol 93:195-198

Kajak A, Andrzejewska L, Wójcik Z (1968) The role of spiders in the decrease of damages caused by Acridoidea on meadows: experimental investigations. Ekol Pol A 16:755-764

Kajak A, Breymeyer A, Petal J (1971) Productivity investigation of two types of meadows in the Vistula Valley. XI. Predatory arthropods. Ekol Pol A 19:223-233

Kirchner W (1964) Bisher Bekanntes über die forstliche Bedeutung der Spinnen-Versuch einer Literaturanalyse. Waldhygiene 5:161-198

Kirchner W (1967) In welchem Masse beeinflussen Spinnen die Mortalitatsrate des Eichenwicklers (Tortrix viridana L.)? Waldhygiene 7:23-31

Kiritani K, Kawahara S, Sasaba T, Nakasuji T (1972) Quantitative evaluation of predation by spiders on the green leafhopper, Nephotettix cincticeps Uhler by sight count method. Res Popul Ecol 13:187-200

Kitazawa Y (1967) Community metabolism of soil invertebrates in forest ecosystems of Japan. In: Petrusewicz K (ed) Secondary productivity of terrestrial ecosystems. Polish Academy of Sciences, Warsaw, pp 649-661

Kuitunen M, Törmälä T (1983) The food of Treecreeper Certhia f. familiáris nestlings in southern Finnland. Ornis Fenn 60:42-44

LaSalle J (1990) Tetrastichinae (Hymenoptera: Eulophidae) associated with spider egg sacs. J Nat Hist 24:1382-1385

Lawrence KL, Wise DH (2000) Spider predation on forest-floor Collembola and evidence for indirect effects on decomposition. Pedobiologia 44:33-39

Lubin YD (1978) Seasonal abundance and diversity of web-building spiders in relation to habitat structure on Barro Colorado Island, Panama. J Arachnol 6:31-51

Lubin Y, Henschel J (1996) The influence of food supply on foraging behaviour in a desert spider. Oecologia 105:64-73

Luczak J (1975) Spider communities of the crop fields. Pol Ecol Stud 1: 93-110

Luczak J (1979) Spiders in agrocoenoses. Pol Ecol Stud 5:151-200

Main BY (1956) Taxonomy and biology of the genus Isometroides Keyserling (Scorpionida). Aust J Zool 4:158-164

Malaisse F, Benoit PLG (1979) Contribution à l'étude de l'écosystème forêt claire (Miombo) au Shaba (Zaire). Rev Zool Afr 93:485-499

Malt S (1996) Untersuchungen zur Rolle ausgewählter netzbauender Spinnen (Araneida) im trophischen Beziehungsgefüge von Halbtrockenrasen. Friedrich-Schiller-Universität Jena, Dissertation

Marques OAV, Stender-Oliveira F, Sawaya RJ, França FGR (2006) Ecology of the colubrid snake Pseudablabes agassizii in southeastern South America. Herpetol J 16:37-45

Meyer E, Schwarzenberger I, Stark G, Wechselberger G (1984) Bestand und jahreszeitliche Dynamik der Bodenmakrofauna in einem inneralpinen Eichenmischwald (Tirol, Osterreich). Pedobiologia 27:115-132

Miller F, Obrtel R (1975) Soil surface spiders in a lowland forest. Acta Sc Nat Brno 9:1-40

Mispagel ME, Sleeper EL (1983) Density and biomass of surfacedwelling macroarthropods in the northern Mojave Desert. Environ Entomol 12:1851-1857 
Moulder BC, Reichle DE (1972) Significance of spider predation in the energy dynamics of forest-floor arthropod communities. Ecol Monogr 42:473-498

Muma MH, Stone KJ (1971) Predation of Gasteracantha cancriformis (Arachnida: Araneidae) eggs in Florida citrus groves by Phalacrotophora epeirae (Insecta: Phoridae) and Arachnophaga ferruginea (Insecta: Eupelmidae). Fla Entomol 54:305-310

Naef-Daenzer L, Naef-Daenzer B, Nager RG (2000) Prey selection and foraging performance of breeding Great Tits Parus major in relation to food availability. J Avian Biol 31:206-214

Nakamura N, Nakamura K (1977) Population dynamics of the chestnut gall wasp, Dryocosmys kuryphilus Yasumatsu (Hymenoptera: Cynipidae) V. Estimation of the effect of predation by spiders on the mortality of imaginal wasps based in the precipitin test. Oecologia 27:97-116

Nentwig W (1987) The prey of spiders. In: Nentwig W (ed) Ecophysiology of spiders. Springer, Berlin-Heidelberg, pp 249-263

Niijima K (1998) Effects of outbreak of the train millipede Parafontaria laminata armigera Verhoeff (Diplopoda: Xystodesmidae) on litter decomposition in a natural beech forest in Central Japan. 1. Density and biomass of soil invertebrates. Ecol Res 13:41-53

Noyes JS (1977) The encyrtid genus Amira, parasites of spider eggs (Hymenoptera). Syst Entomol 2:49-51

Nyffeler M (1976) Diel activity patterns, prey composition, and prey consumption rate of the orb-weaving spiders Araneus diadematus and Nuctenea umbratica in a garden in Höngg (Zurich). Unpublished M.Sc. Thesis. Swiss Federal Institute of Technology Zurich

Nyffeler M (1982) Field studies on the ecological role of the spiders as insect predators in agroecosystems (abandoned grassland, meadows, and cereal fields) Ph.D. Dissertation. Swiss Federal Institute of Technology Zurich

Nyffeler M (1999) Prey selection of spiders in the field. J Arachnol 27: $317-324$

Nyffeler M (2000) Ecological impact of spider predation: a critical assessment of Bristowe's and Turnbull's estimates. Bull Br Arachnol Soc 11:367-373

Nyffeler M, Benz G (1978) Prey selection by web spiders Argiope bruennichi (Scop), Araneus quadratus $\mathrm{Cl}$, and Agelena labyrinthica (Cl) on fallow land near Zurich, Switzerland. Rev Suisse Zool 85: 747-757

Nyffeler M, Benz G (1979) Studies on the ecological importance of spider populations for the vegetation of cereal and rape fields. $Z$ Angew Entomol 87:348-376

Nyffeler M, Benz G (1987) Spiders in natural pest control: a review. J Appl Entomol 103:321-339

Nyffeler M, Benz G (1988a) Feeding ecology and predatory importance of wolf spiders (Pardosa spp.) (Araneae, Lycosidae) in winter wheat fields. J Appl Entomol 106:123-134

Nyffeler M, Benz G (1988b) Prey and predatory importance of micryphantid spiders in winter wheat fields and hay meadows. J Appl Entomol 105:190-197

Nyffeler M, Benz G (1989) Foraging ecology and predatory importance of a guild of orb-weaving spiders in a grassland habitat. J Appl Entomol 107:166-184

Nyffeler M, Sunderland KD (2003) Composition, abundance and pest control potential of spider communities in agroecosystems: a comparison of European and US studies. Agric Ecosyst Environ 95: 579-612

Nyffeler M, Breene RG, Dean DA, Sterling WL (1990) Spiders as predators of arthropod eggs. J Appl Entomol 109:490-501

Nyffeler M, Sterling WL, Dean DA (1992) Impact of the striped lynx spider (Araneae: Oxyopidae) and other natural enemies on the cotton fleahopper (Hemiptera: Miridae) in Texas cotton. Environ Entomol 21:1178-1188

Nyffeler M, Dean DA, Sterling WL (1994a) Insectivorous activities of spiders in United States field crops. J Appl Entomol 118:113-128
Nyffeler M, Sterling WL, Dean DA (1994b) How spiders make a living. Environ Entomol 23:1357-1367

Nyffeler M, Olson EJ, Symondson WOC (2016) Plant-eating by spiders. J Arachnol 44:15-27

Oedekoven MA, Joern A (1998) Stage-based mortality of grassland grasshoppers (Acrididae) from wandering spider (Lycosidae) predation. Acta Oecol 19:507-515

O'Grady PM, Bonacum J, DeSalle R, Val FC (2003) The placement of Engiscaptomyza, Grimshawomyia, and Titanochaeta, three clades of endemic Hawaiian Drosophilidae (Diptera). Zootaxa 159:1-16

Ohl M (2004) Annotated catalog of the Mantispidae of the world (Neuroptera). Contributions on Entomology, International 5:131-262

Pape T (1996) Catalogue of the Sarcophagidae of the world (Insecta: Diptera). Memoirs of Entomology, International 8:1-558

Peaslee JE, Peck WB (1983) The biology of Octonoba octonarius (Muma) (Araneae: Uloboridae). J Arachnol 11:51-67

Pekár S, Toft S (2015) Trophic specialisation in a predatory group: the case of prey-specialised spiders (Araneae). Biol Rev 90:744-761

Persson T, Lohm U (1977) Energetical significance of the annelids and arthropods in a Swedish grassland soil. Ecol Bull 23:1-211

Persson T, Baath E, Clarholm M, Lundkvist H, Soderstrom BE, Sohlenius B (1980) Trophic structure, bio- mass dynamics and carbon metabolism of soil organisms in scots pine forest. Ecol Bull 32: 419-459

Petersen H, Luxton M (1982) A comparative analysis of soil fauna populations and their role in decomposition processes. Oikos 39:287-388

Pitts JP, Wasbauer MS, von Dohlen CD (2006) Preliminary morphological analysis of relationships between the spider wasp subfamilies (Hymenoptera: Pompilidae): revisiting an old problem. Zool Scr 35: 63-84

Platnick NI (2014) The world spider catalog, version 15.0. American Museum of Natural History. Available: http://research.amnh.org/iz/ spiders/catalog/ Accessed 14 November 2014

Poinar GO Jr (1987) Nematode parasites of spiders. In: Nentwig W (ed) Ecophysiology of spiders. Springer, Berlin-Heidelberg, pp 299-308

Pointing PJ (1966) A quantitative field study of predation by the sheetweb spider, Frontinella communis, on European pine shoot moth adults. Can J Zoolog 44:265-273

Polis GA (1991) The ecology of desert communities. University of Arizona Press, Tucson

Polis GA, Hurd SD (1995) Extraordinarily high spider densities on islands: flow of energy from the marine to terrestrial food webs and the absence of predation. Proc Natl Acad Sci U S A 92:4382-4386

Polis GA, McCormick SJ (1986) Scorpions, spiders and solpugids: predation and competition among distantly related taxa. Oecologia 71:111-116

Polis GA, Yamashita T (1991) The ecology and importance of predaceous arthropods in desert communities. In: Polis GA (ed) The ecology of desert communities. University of Arizona Press, Tuscon, pp $180-222$

Polis GA, Myers CA, Holt RD (1989) The ecology and evolution of intraguild predation: potential competitors that eat each other. Annu Rev Ecol Syst 20:297-330

Poulin B, Lefebvre G (1996) Dietary relationships of migrant and resident birds from a humid forest in central Panama. Auk 113:277-287

Pulawski WJ (2016) Catalog of Sphecidae sensu lato (=Apoidea excluding Apidae). California Academy of Sciences, San Francisco. http://researcharchive.calacademy.org/research/entomology/ entomology_resources/hymenoptera/sphecidae/number_of species.pdf Accessed 10 September 2016

Pulz R (1987) Thermal and water relations. In: Nentwig W (ed) Ecophysiology of spiders. Springer, Berlin-Heidelberg, pp 26-55

Ramírez MG (1995) Natural history of the spider genus Lutica (Araneae, Zodariidae). J Arachnol 23:111-117

Raub F, Höfer H (2010) Guild structures and biomass of spiders in forests and agroforestry systems in central Amazonia, Brazil. 18th 
International Congress of Arachnology, 11-17 07 2010, Siedlce, Poland, p. 361

Reagan DP, Waide RB (1996) The food web of a tropical rain forest. University of Chicago Press, Chicago

Reichle DE, Crossley DA Jr (1967) Investigations of heterotrophic productivity in forest insect communities. In: Petrusewicz K (ed) Secondary productivity of terrestrial ecosystems (principles and methods). Institute of Ecology, Warsaw, pp 563-587

Robinson MH, Robinson B (1970) Prey caught by a sample population of the spider Argiope argentata (Araneae: Araneidae) in Panama: a year's census data. Zool J Linn Soc-Lond 49:345-357

Robinson MH, Robinson B (1973) Ecology and behavior of the giant wood spider Nephila maculata (Fabr.) in New Guinea. Smithson Contrib Zool 149:1-73

Robinson MH, Robinson B (1974) A census of web-building spiders in coffee plantations at Wau, New Guinea, and an assessment of their insecticidal effects. Trop Ecol 15:95-107

Robinson MH, Lubin YD, Robinson B (1974) Phenology, natural history and species diversity of web-building spiders on three transects at Wau, New Guinea. Pac Insects 16:117-163

Russell-Smith A, Stork NE (1994) Abundance and diversity of spiders from the canopy of tropical rainforests with particular reference to Sulawesi, Indonesia. J Trop Ecol 10:545-558

Rypstra AL (1986) Web spiders in temperate and tropical forests: relative abundance and environmental correlates. Am Midl Nat 115:42-51

Santana M, Eberhard WG, Bassey G, Prestwich KN, Briceno RD (1990) Low predation rates in the field by the tropical spider Tengella radiata (Araneae: Tengellidae). Biotropica 22:305-309

Saugier B, Roy J, Mooney HA (2001) Estimations of global terrestrial productivity: converging toward a single number? In: Roy J, Saugier B, Mooney HA (eds) Terrestrial global productivity. Academic Press, San Diego, pp 543-557

Schaefer M (1990) The soil fauna of a beech forest on limestone: trophic structure and energy budget. Oecologia 82:128-136

Scheu S, Albers D, Alphei J, Buryn R, Klages U, Migge S, Platner C, Salamon JA (2003) The soil fauna community in pure and mixed stands of beech and spruce of different age: trophic structure and structuring forces. Oikos 101:225-238

Schmitz OJ (1993) Trophic exploitation in grassland food chains: simple models and a field experiment. Oecologia 93:327-335

Schmitz OJ (1998) Direct and indirect effects of predation and predation risk in old-field interaction webs. Am Nat 151:327-342

Schmitz OJ, Beckerman AP, O'Brien KM (1997) Behaviorally mediated trophic cascades: effects of predation risk on food web interactions. Ecology 78:1388-1399

Schultz M, Wainer J (1997) Diet of the golden-tipped bat Kerivoula papuensis (Microchiroptera) from north-eastern New South Wales, Australia. J Zool 243:653-658

Selden PA (2016) Origins of land animals. In: Kliman R (ed) Encyclopedia of evolutionary biology. Academic Press, Oxford, pp 288-295

Selden PA, Shear WA, Bonamo PM (1991) A spider and other arachnids from the Devonian of New York, and reinterpretations of Devonian Araneae. Palaeontology 34:241-281

Shine R (1986) Evolutionary advantages of limblessness: evidence from the pygopodid lizards. Copeia 2:525-529

Shook RS (1978) Ecology of the wolf spider, Lycosa carolinensis Walckenaer (Araneae, Lycosidae) in a desert community. J Arachnol 6:53-64

Silva D (1996) Species composition and community structure of Peruvian rainforest spiders: a case study from a seasonally inundated forest along the Samiria river. Rev Suisse Zool, vol hors serie:597-610
Snyder WE, Wise DH (2000) Antipredator behavior of spotted cucumber beetle (Coleoptera: Chrysomelidae) in response to predators that pose varying risks. Environ Entomol 29:35-42

Soley FG, Jackson RR, Taylor PW (2011) Biology of Stenolemus giraffa (Hemiptera: Reduviidae), a web invading, araneophagic assassin bug from Australia. New Zeal J Zool 38:297-316

Stöckli A (1950) Die Ernährung der Pflanze in ihrer Abhängigkeit von der Kleinlebewelt des Bodens. Z Pflanzenernähr Bodenkd 48: 264-279

Sunderland KD, Fraser AM, Dixon AFG (1986) Field and laboratory studies on money spiders (Linyphiidae) as predators of cereal aphids. J Appl Ecol 23:433-447

Symondson WOC, Sunderland KD, Greenstone MH (2002) Can generalist predators be effective biocontrol agents? Annu Rev Entomol 47:561-594

Tanhuanpää M, Ruohomäki K, Uusipaikka E (2001) High larval predation rate in non-outbreaking populations of a geometrid moth. Ecology 82:281-289

Thomas CFG, Brain P, Jepson PC (2003) Aerial activity of linyphiid spiders: modeling dispersal distances from meteorology and behaviour. J Appl Ecol 40:912-927

Turnbull AL (1960) The prey of the spider Linyphia triangularis (Clerck)(Araneae, Linyphiidae). Can J Zoolog 38:859-873

Turnbull AL (1973) Ecology of the true spiders. (Araneomorphae). Annu Rev Entomol 18:305-348

Van der Drift J (1951) Analysis of the animal community in a beech forest floor. Tijdschr Entomol 94:1-168

Van Hook RI (1971) Energy and nutrient dynamics of spider and orthopteran populations in a grassland ecosystem. Ecol Monogr 41:1-26

Van Sluys M, Rocha CFD (1998) Feeding habits and microhabitat utilization by two syntopic Brazilian Amazonian frogs Hyla minuta and Pseudopaludicula sp. (gr. falcipes). Rev Bras Biol 58:559-562

Vincent LS (1985) The first record of a Tachinid fly as an internal parasitoid of a spider (Diptera: Tachinidae; Araneae: Antrodiaetidae). Pan-Pac Entomol 6:224-225

Vitousek P, Ehrlich PR, Ehrlich AH, Matson P (1986) Human appropriation of the products of photosynthesis. Bioscience 36:368-373

Weathers WW, Weathers D (1983) Birds of Southern California's deep canyon. University of California Press, Berkeley

Welbourn WC, Young OP (1988) Mites parasitic on spiders, with a description of a new species of Eutrombidium (Acari, Eutrombidiidae). J Arachnol 16:373-385

Wheeler T (2003) Ride a pale horse: diversity and host associations of Pseudogaurax (Diptera: Chloropidae), predators of arachnids. Abstract. 2003 Joint Annual Meeting of the Entomological Society of Canada and The Entomological Society of British Columbia. 1-5 November 2003. Kelowna, British Columbia

Wise DH (1993) Spiders in ecological webs. Cambridge University Press, Cambridge

Yanoviak SP, Kragh G, Nadkarni NM (2003) Spider assemblages in Costa Rican cloud forests: effects of forest level and forest age. Stud Neotrop Fauna E 38:145-154

Yodzis P (2001) Must top predators be culled for the sake of fisheries? Trends Ecol Evol 16:78-84

Ysnel F (1993) Relationship between food intake and spider size in temperate zones: experimental model for an orb-weaving spider. Mem Queensl Mus 33:687-692

Zitnanská O (1981) Studie über die Lebensgemeinschaften der Spinnen in dem Waldtyp Querco-Caepinetum in Bab bei Nitra. Acta Fac Rerum Nat Univ Comenianae Zool 25:39-57 